\title{
Morphological study of Nyctanthes arbor-tristis L. fruit and seed in different growth stages
}

\author{
Keya Modak \& Monoranjan Chowdhury* \\ Taxonomy of Angiosperms \& Biosystematics Lab., Department of Botany, University of North Bengal, Raja Rammohunpur, Darjeeling, West \\ Bengal 734 013, India \\ *Email: mono_malda@yahoo.co.in
}

\section{ARTICLE HISTORY}

Received: 21 March 2021

Accepted: 08 July 2021

Available online: 19 August 2021

KEYWORDS

Growth

LM

SEM

Stomata

Trichome

ANOVA

\begin{abstract}
Qualitative and quantitative morphological characterization in different growth stages of Nyctanthes arbor-tristis L. fruits and seeds were investigated. Capsules are compressed, two celled, green, cordate to round or elliptical with one flattened seed in each half. Both LM and SEM study were conducted to gather micromorphological features of matured epicarp and seed testa. Non-glandular, uniseriate, slender trichome and anomocytic stomata were found on epicarp, whereas same was absent on seeds. Some crystalline substance was noticed on both epicarp cells and seed testa. The fruiting stages were divided into 0 to $\mathrm{V}$ stages starting from first day of fruit appearing and total required days needed for maturity. Remarkable differences such as fruit and seed size, weight and colour were varied in each stage. Significance of surface micromorphology of matured epicarp and seed testa of N. arbor-tristis is also discussed here. Single-factor ANOVA analysis and Regression were performed to test the significance level of the studied parameters and their relationship.
\end{abstract}

\section{Introduction}

Herbal medicine is now used by about $80 \%$ of the world population for primary healthcare (1). According to extensive scientific research, plantderived drugs also play an important role as a source of bioactive compounds for the past two decades (1). Nyctanthes arbor-tristis L. is native to India among the two members of the genus throughout the world. $N$. arbor-tristis (Oleaceae) is very important in phytochemical, pharmaceutical as well as industrial purposes $(2,3)$. Dry matured fruits contain significant amounts of glycosides, tannins, phenols and steroids, which are supposed to be responsible for anticancerous properties (4).

Seeds of the plant also show some properties like antifungal, anti-bacterial (against gram-negative bacteria), anti-allergic, anti-parasitic, anti-amoebic, anti-anaemic, anti-inflammatory, immunemodulatory, anti-hair fall and anti-leishmanial (4-8). The seed is also used in ayurvedic treatment against cough and cold, baldness, piles, and it's advised to take dry fruits to get rid of cough (9).

Some workers reported that different stages of maturity of this fruit and seed yield different chemical components with varying concentrations $(10,11)$. Aged green seeds and ripe seeds of $N$. arbor-tristis show variations in physicochemical characters, fatty acid concentrations, and also on their existence (10, 11). Some fatty acids like Caproic acid, Capric acid, Undecanoic acid, Tridecanoic acid are not found in green seeds but present in ripe seeds (10).

Therefore, the primary goal of the work is to investigate the specific growth season to get optimum size matured green and ripe fruit of $N$. arbor-tristis. The present work highlights the qualitative and quantitative morphological characteristics of fruit and seed in various stages of development of $N$. arbortristis. Observed data through LM and SEM were useful for understanding the surface (epicarp) ornamentation of the matured fruit and seed. The gathered data can be helpful to analyze the exact fruit and seed size, weight, maturity time period in specific growth season of the study area. This phenological data may be helpful to agricultural practitioners and biochemists to collect specific matured fruit (matured green or matured ripe) and analyze the chemical components of different stages of fruit development, as earlier workers mentioned that the variations of physicochemical characters of this fruit occurs according to maturity. Another objective of the work is to evaluate the significance of morphology and surface sculpturing of this medicinally important matured fruit and seed. 


\section{Materials and Methods}

\section{Sample collection and meteorological data}

In each stage $(0-V)$, average 30 samples (flowers, fruits and seeds) were collected from six matured plants of $N$. arbor-tristis L. from Darjeeling and Jalpaiguri districts of West Bengal during flowering and fruiting season from late September or October 2019 to February 2020 for fruit, seed growth statistical study. Blooming to fruit maturity period was divided into stage 0 to stage $\mathrm{V}$. Blooming condition was considered as stage 0 and the inflorescence (trichotomous cyme) was marked with tagging. After that, stage I was considered 25 days later of stage 0 and stage II observation from 25 days later of stage I and so on up to stage V.

Average minimum range of temperature of the study area was $10-11^{\circ} \mathrm{C}$, and the highest range was $26-30^{\circ} \mathrm{C}$. Similarly, the average minimum range of rainfall was about $11-14 \mathrm{~mm}$, and the highest range of rainfall was 137-141 $\mathrm{mm}$ during the floweringfruiting season. Soil $\mathrm{pH}$ of the study area was 5-6, tested with $\mathrm{pH}$ paper following the soil $\mathrm{pH}$ protocol (12).

\section{Laboratory methods}

The specimen was matched with different floras (13, 14) and herbaria (NBU) for proper identification. Then, voucher specimen was prepared with conventional herbarium technique (15) and deposited to NBU herbarium (accession number NBU11566). For fruit and seed morphology, different stages of fruit growth were investigated to record their colour, size, surface texture, weight etc. The macro morphological description was followed by the provided terminology of an earlier worker (16). The micromorphological observations of cell pattern of fruit and seed, stomata, trichomes, sclereids were conducted through light microscopy (LM) and scanning electron microscopy (SEM).

\section{LM study}

Thin membranous peeling was done by forceps from the epicarp of the fruit and seed testa for micromorphological study. Peeled samples were stained with $1 \%$ safranin and then mounted with $10 \%$ glycerine after washing the excess stain (17). The prepared samples were observed on a slide under an upright trinocular light microscope (Magnus model no. 528013). Micromorphological terminology was followed from earlier studies (18-21).

\section{SEM study}

Matured, entire fruit and fruit peelings were selected for SEM study and then they were put in a desiccator for 1-2 days for drying, then gold coated with a sputter coater (model: JEOL DII-29030SCTR) for about $2 \mathrm{~min}$ in fully dried conditions. After that, fruit micromorphological observation was conducted through Scanning Electron Microscope (model: JSMIT100) with about 2-8 kV energy. Matured seed testa was studied in same manner.

\section{Data analysis}

All the quantitative morphological data were tabulated as mean \pm standard deviation of the observed data. Graphs were created with mean values of different parameters. ANOVA analysis was performed in Microsoft excel based on all mean values of quantitative parameters to test the degree of significance level between different attributes under study.

Stomatal frequency and stomatal index were calculated according to the standard formula described (22).

$$
\begin{aligned}
\text { Stomatal frequency }(\mathrm{SF}) & =\frac{\text { Number of stomata }}{\text { Microscopic field }} \\
\text { Stomatal index (SI) } & =\frac{S \times 100}{E+S}
\end{aligned}
$$

Here, $\mathrm{E}=$ Total number of epidermal cells / microscopic field, $\mathrm{S}=$ Total number of stomata $/$ microscopic field.

\section{Results}

\section{Fruit development and Macromorphology}

Flowering period was started in late September or starting of October 2019 and noted the ovary size. After blooming (anthesis), observations were carried out once in eight days, but no remarkable change was noticed up to 16 days. Then small fruit development was found at about $25^{\text {th }}$ days after blooming and this stage was considered as stage I, further observations were carried out up to full maturity (green) about after 4 months.

It was observed that fruit length, breadth and weight was increased from stage 0 to stage $\mathrm{V}$, but after stage V, it was constant, except fruit colour (Fig. 1, 2, 3D, 3I). After February, the ripening stage only showed colour changes from deep green to brownish

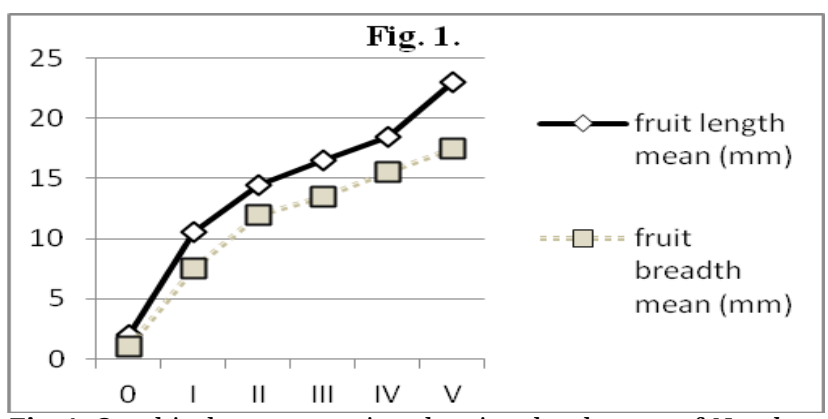

Fig. 1. Graphical representation showing the changes of N. arbortristis fruit length $(\mathrm{mm})$ and breadth $(\mathrm{mm})$ at different growth stages.

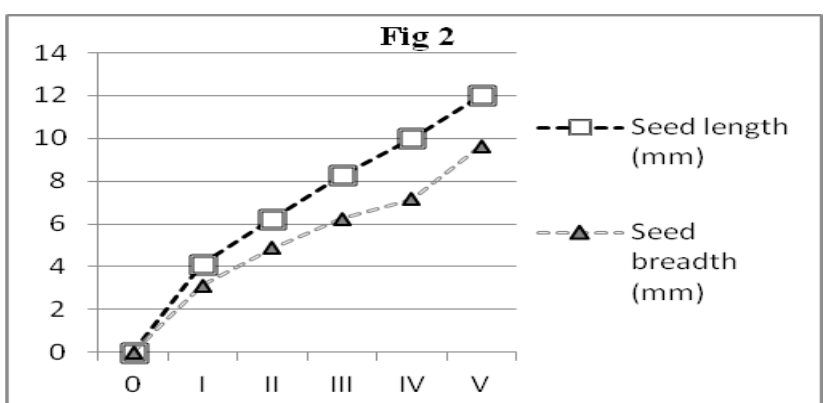

Fig. 2. Graphical representation showing the changes of N. arbortristis seed length $(\mathrm{mm})$ and breadth $(\mathrm{mm})$ at different growth stages.

and mostly fall on to the ground. As the constant 

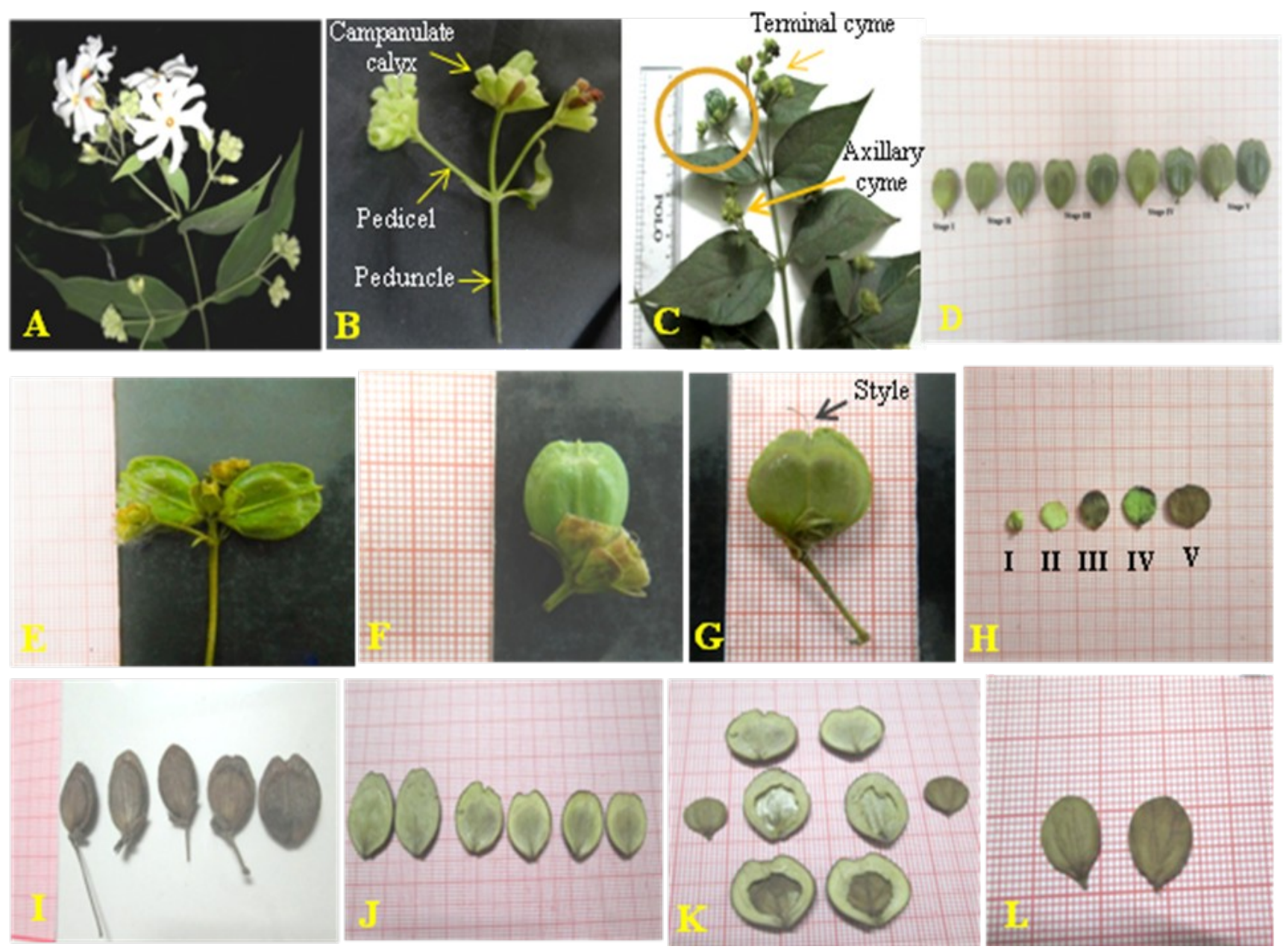

Fig.3. N. arbor-tristis L.: A. A flowering twig, B. Inflorescence parts with very small developing fruit, C. Matured green fruit with twig showing axial \& terminal inflorescence, D. \& H. Fruit \& seed development in different stages; E. Development of two fruits per cluster of inflorescence; F. \& G. Cordate and rounded green matured fruits in mm graph scale with mucronate, notched apex with and without style; I. Matured, ripen fruits; J. Each halves of three ripe fruits, K. Different parts of ripe fruits, L. Two seeds of a fruit.

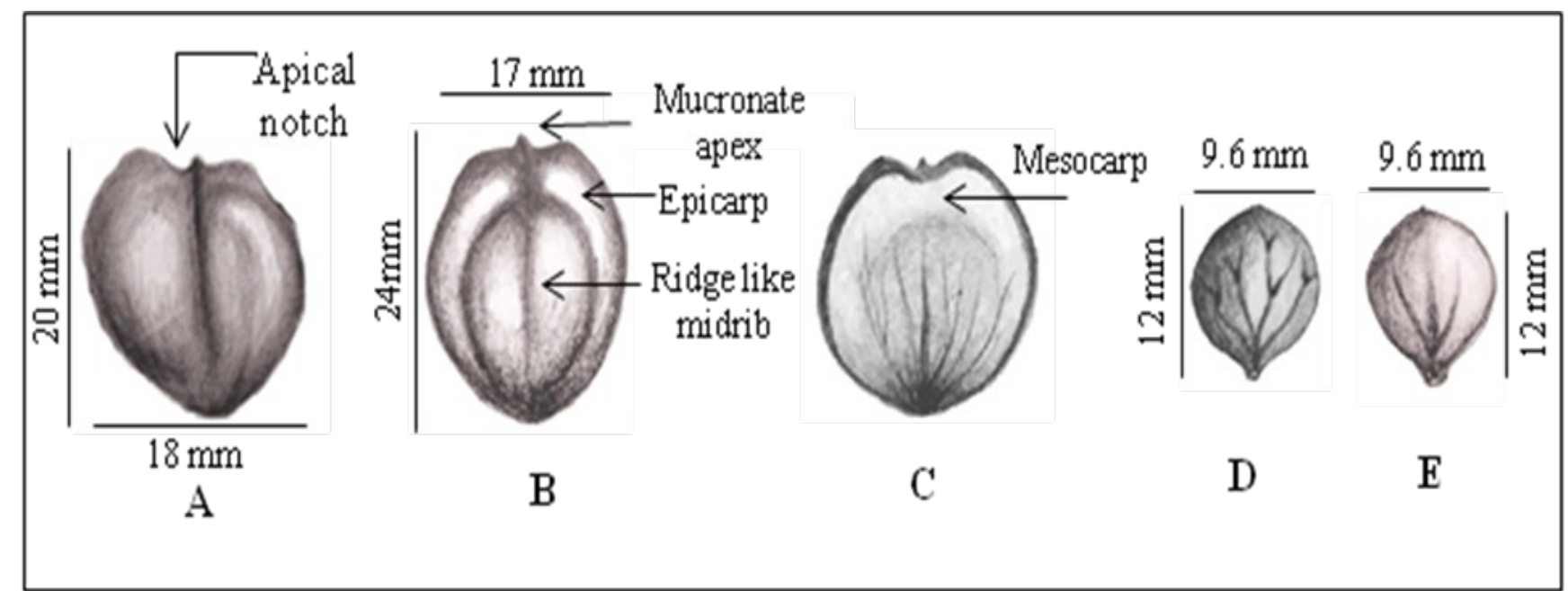

Fig. 4. Illustrations of different fruit parts of N. arbor-tristis L. A. \& B. Rounded or cordate shaped and elliptical fruits, C. One half of a fruit showing reticulate mesocarp, D. \& E. Two sides of a seed with venation and average length, breadth.

stability of the studied characters (except colour), the ripening stage was not included in the data table and only photographs are provided here (Fig. 3). Surprisingly, only 1-2 fruits developed from a cymose inflorescence (10-15 flowers in a peduncle) but not all the developing fruits become matured and only $50-60 \%$ developing fruits become matured with seeds. Elliptical fruit showed less number of mature seed production (50-52\%), the fact behind this result was unknown to us.

The ovary is inferior, two-chambered, each containing one ovule. Prominent septum was visible in the middle of the ovary (Fig. 5A). The ovary length ranges from $1.5-2.5 \mathrm{~mm}$ and breadth was $1 \mathrm{~mm}$ at stage 0 (Fig. $5 \mathrm{~B}$; Table 1). Style may or may not be 
present at maturity (Fig. 3F, 3G). Numerous minute $(\leq 1 \mathrm{~mm})$ whitish hairs were observed at the ovary base (Fig. 5C). The ovary was green (due to immaturity) in colour and its weight was very light ( $\leq 1 \mathrm{mg}$ ).

The fruit (20-24 × 17-18 $\left.\mathrm{mm}^{2}\right)$ was compressed or flattened, separated into two-chambered, twoseeded (1 in each half or locule), indehiscent, cordate shaped or orbicular capsule and sometimes slightly elliptical in appearance. According to some workers, the fruit of $N$. arbor-tristis is a shizocarpic capsular type $(3,23)$. Mucronate apex was present at the middle of the fruit apical notch (Fig. 4A, 4B). Sometimes stigma with a small part of style was seen in cordate fruits at the apical notch region up to the unripe condition (Fig. 3G). Fruit colour was gradually changed from light green to deep green and ultimately light to deep blackish brown (Fig. 3D, 3I; Table 1). The mesocarp was light brown in colour at ripening (Fig. 3J, 4C). Two halves were attached throughout the margin and veined reticulate. A ridge like midrib was prominent in the middle part of fruit base to apex in each side of the fruit, and it was subtended by mucronate apex at the apical notch (Fig. 3E, 4B). This midrib and neighboring veins originated from a single point of the fruit and pedicel juncture. The surfaces of both ripe and green matured fruits were rough in texture.
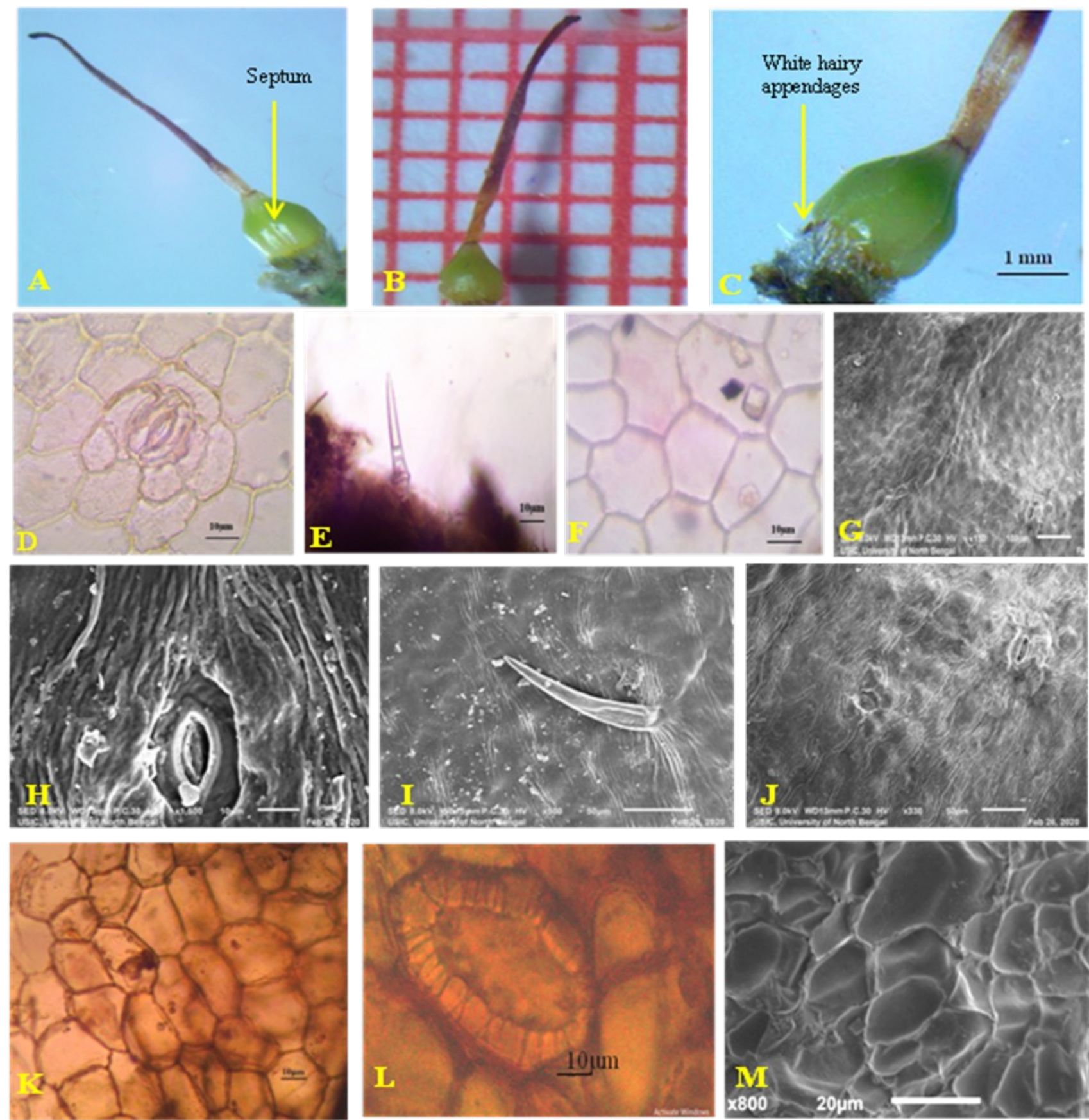

Fig. 5. $N$. arbor-tristis L.: A. Gynoecium with septum at the middle of the ovary, B. Gynoecium with mm graph scale, C. Whitish hairs at ovary base, D.-J. LM \& SEM study of fruit epicarp: D. Anomocytic stomata with epicarp cells showing slightly sinuos wall, E. \& I. Uniseriate, slender, non-glandular trichome, F. Polygonal exocarp cells with prismatic crystals, G. Epicarp surface, H. Stoma with striated cuticle, J. Embedded stomata in Epicarp cell, K.-M. LM \& SEM study of seed testa: K. \& M. Polygonal testa cells, L. Brachysclereid. 
The seeds were flattened, obovate, veined reticulate, and two in number in each fruit. The size of matured seed was 11-14 × 8-11.5 mm² (Fig. 3L, 4D, 4E; Table 2). Elongated fruits showed slightly longer seed and less width than those of cordate shaped fruits, but both types showed a more or less similar size ratio of fruit and seed. The seed colour gradually changed from greenish-white to brown (Table 2). Seeds can be easily separated when the fruit gets fully matured and ripened. Observed weight for matured seed range was 90-140 mg. which were mostly elongated and spread throughout the microscopic field with different curves (Fig. $5 \mathrm{H}$, 5J). These striations were very close to the guard cells and few were oblique in appearance (Fig. 5H). Some granules like particles (without any specific shape) were found near the stomata and trichomes (Fig. 5H, 5I). Stomata were absent in the seed surface.

\section{Trichome}

Slender, erect, uniseriate, pointed tip trichomes were found in the outer cuticular surface of matured fruits

Table 1. Morphology of fruit development from flowering condition (ovary) to full maturity

\begin{tabular}{|c|c|c|c|c|c|c|c|c|c|}
\hline \multirow{2}{*}{$\begin{array}{l}\text { Stages of } \\
\text { fruit } \\
\text { develop } \\
\text { ment }\end{array}$} & \multirow{2}{*}{$\begin{array}{l}\text { Fruit dev. } \\
\text { days after } \\
\text { blooming }\end{array}$} & \multicolumn{2}{|c|}{ Fruit length (mm) } & \multicolumn{2}{|c|}{ Fruit breadth (mm) } & \multirow{2}{*}{$\begin{array}{l}\text { Avg. Fruit } \\
\text { size }\left(\mathrm{mm}^{2}\right)\end{array}$} & \multirow{2}{*}{$\begin{array}{l}\text { Avg. Fruit wt. } \\
\text { with attached } \\
\text { bracts (mg) }\end{array}$} & \multirow{2}{*}{$\begin{array}{l}\text { Avg. Fruit wt. } \\
\text { without bracts } \\
\text { (mg) }\end{array}$} & \multirow[b]{2}{*}{ Colour } \\
\hline & & Ln. range & Ln. Avg. & Br. range & Br. Avg. & & & & \\
\hline 0 & 0 & $1.50-2.50$ & $2 \pm 0.29$ & 1.00 & $1 \pm 0$ & $2 \pm 0.29$ & $2.43 \pm 0.68$ & $1.30 \pm 0.535$ & Ovary green \\
\hline I & 25 & 8-13 & $10.50 \pm 1.34$ & $5.00-10.00$ & $7.50 \pm 1.51$ & $80.21 \pm 24.07$ & $150.13 \pm 4.15$ & $138.60 \pm 5.88$ & $\begin{array}{l}\text { Fruit light } \\
\text { green }\end{array}$ \\
\hline II & 50 & $14-15$ & $14.50 \pm 0.48$ & $11.50-12.50$ & $12.00 \pm 0.44$ & $174.03 \pm 9.22$ & $260.3 \pm 28.68$ & $210.3 \pm 16.65$ & Light green \\
\hline III & 75 & $16-17$ & $16.54 \pm 0.42$ & $13.00-14.00$ & $13.48 \pm 0.44$ & $223.00 \pm 10.45$ & $344.83 \pm 12.05$ & $320.10 \pm 13.62$ & $\begin{array}{l}\text { Light to deep } \\
\text { green }\end{array}$ \\
\hline IV & 100 & $18-19$ & $18.50 \pm 0.43$ & $15-16$ & $15.50 \pm 0.42$ & $286.86 \pm 11.74$ & $380.80 \pm 10.39$ & $354.83 \pm 9.69$ & Deep green \\
\hline V & 125 & $20-24$ & $23.00 \pm 1.51$ & $17-18$ & $17.51 \pm 0.41$ & $402.73 \pm 29.12$ & $450.23 \pm 7.29$ & $423.37 \pm 5.02$ & $\begin{array}{l}\text { Deep green and } \\
\text { after that } \\
\text { become } \\
\text { brownish }\end{array}$ \\
\hline
\end{tabular}

Avg: average, Br: breadth, dev: development, G.C.: guard cell, Ln: length, wt: weight.

Table 2. Morphology of seed development from flowering condition (ovary) to full maturity

\begin{tabular}{|c|c|c|c|c|c|c|c|c|}
\hline $\begin{array}{l}\text { Stages of } \\
\text { seed dev. }\end{array}$ & $\begin{array}{l}\text { Seed dev. } \\
\text { days after } \\
\text { flowering }\end{array}$ & $\begin{array}{c}\text { Ln. range } \\
\text { (mm) }\end{array}$ & Avg. Ln. (mm) & $\begin{array}{l}\text { Br. (mm) } \\
\text { range }\end{array}$ & Avg. br. (mm) & Avg. size $\left(\mathrm{mm}^{2}\right)$ & Seed wt. (mg) & Colour \\
\hline 0 & 0 & 0 & 0 & 0 & 0 & 0 & 0 & 0 \\
\hline $\mathrm{I}$ & 25 & $2.5-5$ & $4.13 \pm 0.73$ & $2-4$ & $3.13 \pm 0.74$ & $13.34 \pm 4.95$ & $20.65 \pm 3.85$ & Greenish white \\
\hline II & 50 & $5.5-7$ & $6.25 \pm 0.57$ & $4.5-5.5$ & $4.87 \pm 0.38$ & $30.54 \pm 4.53$ & $30.30 \pm 3.09$ & Light Green \\
\hline III & 75 & $7.5-9$ & $8.27 \pm 0.55$ & $6-6.5$ & $6.25 \pm 0.24$ & $51.78 \pm 4.86$ & $41.40 \pm 3.83$ & Green \\
\hline IV & 100 & 9.5-10.5 & $10.00 \pm 0.41$ & $7-7.5$ & $7.15 \pm 0.19$ & $71.56 \pm 4.52$ & $61.92 \pm 9.89$ & $\begin{array}{l}\text { Green with } \\
\text { light brown }\end{array}$ \\
\hline $\mathrm{V}$ & 125 & $11-14$ & $12.00 \pm 0.96$ & 8-11.5 & $9.63 \pm 1.16$ & $116.16 \pm 20.87$ & $118.41 \pm 17.51$ & $\begin{array}{c}\text { Brown or } \\
\text { blackish } \\
\text { brown }\end{array}$ \\
\hline
\end{tabular}

\section{Micromorphology}

\section{Fruit epicarp cell}

LM study of epicarp showed that cells were polygonal in shape and slightly sinuous in cell wall pattern (Fig. 5D, 5F; Table 3). Cells were compactly arranged and intercellular space was absent. Anomocytic type of stomata was found (Fig. 5D). The ranges of stomatal frequency (SF) and stomatal index (SI) were 16.6783.33 per $\mathrm{mm}^{2}$ and $2.44-8.57$ respectively (Table 3). Cuticular depositions were uneven throughout the surface. SEM observation showed that cuticular cells were arranged in a wavy pattern and stomata were embedded in it (Fig. 5G, 5J).

\section{Seed testa cell}

Based on LM study, it was found that testa cells were polygonal in shape and slightly sinuous to straight in cell wall pattern (Fig. 5K). No intercellular space was found in LM and SEM study (Fig. 5K, 5M; Table 3).

\section{Stomata}

Fruit stomata were anomocytic type, and its pore size was 18.4-21.07 × 5.03-7.91 $\mu^{2}$ in the LM study (Fig. 5D; Table 3). SEM study showed that stomatal guard cells were around by a series of striated cuticles,
(Fig. 5E, 5I; Table 3). Trichomes length ranges from 119.71-200.07 $\mu \mathrm{m}$ (Table 3). SEM study showed that some elongated, parallel patches or striations were also present around the trichomes, like stomatal striations (Fig. 5I). The seed surface was devoid of trichome.

\section{Crystal}

Prismatic crystals were present in fruit epicarp cells and seed testa cells (Table 3). LM study showed that $2-3$ crystals were generally present in few epicarp cells (Fig. 5F).

\section{Sclereids}

Few brachysclereids were observed within matured seed testa cells. The sclereids were various in shapes, with the thickened cell wall and were mostly single (Fig. 5L).

\section{Regression analysis}

Regression analysis was performed to study how the variables depend on each other and what kind of relationship is present between them. Linear regression analysis also interprets the association 
Table 3. Quantitative and qualitative data about fruit and seed surface sculpturing

\begin{tabular}{|c|c|c|c|c|c|c|c|c|}
\hline & Stomata & & & Trichomes & & & Cell pattern & \\
\hline Features & Fruit epicarp & $\begin{array}{l}\text { Seed } \\
\text { testa }\end{array}$ & Features & $\begin{array}{l}\text { Fruit } \\
\text { epicarp }\end{array}$ & Seed testa & Features & Fruit epicarp & Seed testa \\
\hline Type & Anomocytic & \multirow{7}{*}{$\begin{array}{l}\text { Stomata } \\
\text { absent }\end{array}$} & Type: & Uniseriate & \multirow{7}{*}{$\begin{array}{l}\text { Trichomes } \\
\text { absent }\end{array}$} & Shape: & polygonal & Polygonal \\
\hline Pore length: & $18.4-21.07 \mu \mathrm{m}$ & & Length: & $\begin{array}{l}119.71- \\
200.07 \mu \mathrm{m}\end{array}$ & & \multicolumn{2}{|c|}{ Cell wall Pattern: Slightly sinuos } & $\begin{array}{l}\text { Slightly sinuous } \\
\text { to straight }\end{array}$ \\
\hline Pore breadth: & $5.03-7.91 \mu \mathrm{m}$ & & Branching: & Absent & & $\begin{array}{l}\text { Intercellular } \\
\text { space: }\end{array}$ & Absent & Absent \\
\hline G.C. length: & $\begin{array}{l}23.16- \\
38.68 \mu \mathrm{m}\end{array}$ & & Shape: & Slender & & $\begin{array}{l}\text { Surface } \\
\text { sculpture: }\end{array}$ & Wavy & Wavy \\
\hline G.C. breadth: & $\begin{array}{l}17.04- \\
23.01 \mu \mathrm{m}\end{array}$ & & Gland: & Absent & & $\begin{array}{l}\text { Crystalline } \\
\text { structure: }\end{array}$ & $\begin{array}{l}\text { Present very } \\
\text { frequently }\end{array}$ & Present \\
\hline $\begin{array}{l}\text { Stomatal } \\
\text { frequency (SF): }\end{array}$ & $\begin{array}{l}16.67-83.33 \\
\text { per } \mathrm{mm}^{2}\end{array}$ & & Curve: & Absent & & Sclereid & Absent & $\begin{array}{l}\text { Brachysclereid } \\
\text { type }\end{array}$ \\
\hline $\begin{array}{l}\text { Stomatal index } \\
\text { (SI): }\end{array}$ & $2.44-8.57$ & & Base: & $\begin{array}{l}\text { Some patches } \\
\text { present }\end{array}$ & & $\begin{array}{l}\text { Cuticle } \\
\text { deposition layer: }\end{array}$ & Uneven & Uneven \\
\hline
\end{tabular}

between two variables (24). Table 4, 5 and 6 showed regression co-efficient value of fruit length vs breadth, fruit weight vs fruit size and fruit size vs seed size, which were $0.9935,0.9757$ and 0.9842 , respectively.

\section{ANOVA analysis}

It was seen that the p-value of fruit parameters under different developmental stages was $2.42 \mathrm{x}$ $10^{-06}$ (Table 7).

Table 4. Regression statistics summary output of fruit length (mm) and breadth (mm) parameters

\begin{tabular}{lr}
\hline \multicolumn{2}{c}{ Regression statistics } \\
\hline Multiple R & 0.993566 \\
\hline R Square & 0.987174 \\
\hline Adjusted R Square & 0.983968 \\
\hline Standard Error & 0.920093 \\
\hline Observations & 6 \\
\hline
\end{tabular}

Table 5. Regression statistics summary output of fruit weight (mg) and fruit size $\left(\mathrm{mm}^{2}\right)$ parameters

\begin{tabular}{lr}
\hline \multicolumn{2}{c}{ Regression statistics } \\
\hline Multiple R & 0.975727 \\
\hline R Square & 0.952043 \\
\hline Adjusted R Square & 0.940053 \\
\hline Standard Error & 35.18003 \\
\hline Observations & 6 \\
\hline
\end{tabular}

Table 6. Regression statistics summary output of fruit and seed size $\left(\mathrm{mm}^{2}\right)$

\begin{tabular}{lr}
\hline \multicolumn{2}{c}{ Regression statistics } \\
\hline Multiple R & 0.984205 \\
\hline R Square & 0.968659 \\
\hline Adjusted R Square & 0.960824 \\
\hline Standard Error & 28.44106 \\
\hline Observations & 6 \\
\hline
\end{tabular}

\section{Discussion}

The present study will be helpful to other research works which are related to the fruit of Nyctanthes arbor-tristis L. Previously, some workers $(3,25)$ investigated the macro-micro morphology of this plant. The variations of chemical composition of this fruit in different maturity stages, makes it really
Table 7. ANOVA showing the significance level among different parameters of each developmental stage of fruit and seed under study

\begin{tabular}{lcccccc}
\hline ANOVA & & & & & & \\
$\begin{array}{l}\text { Source of } \\
\text { Variation }\end{array}$ & SS & $d f$ & $M S$ & $F$ & P-value & F crit \\
\hline $\begin{array}{l}\text { Between } \\
\text { Groups }\end{array}$ & 551054.3 & 7 & 78722.04 & 8.499822 & $2.42 \mathrm{E}-06$ & 3.123757 \\
\hline $\begin{array}{l}\text { Within } \\
\text { Groups }\end{array}$ & 370464.4 & 40 & 9261.611 & & & \\
\hline Total & 921518.7 & 47 & & & & \\
\hline $\begin{array}{l}\text { Significant at } \mathrm{p}<0.01 \\
\text { level. }\end{array}$ & & & &
\end{tabular}

necessary for elaborate investigation on its developmental process at regular intervals after blooming along with comparative qualitative and quantitative surface morphology by both LM and SEM study.

The length, breadth and colour of the fruit, seed gradually changes from the starting up to the maturity period and turns brownish or blackishbrown and ultimately fall to the ground (Fig. 1, 2; Table 1, 2). During this developmental process, the epicarp becomes harder according to colour changes. The two halves can be separated easily in stage V, where as other quite problematic. From the regression analysis, it was observed that fruit length and breadth, fruit size and seed size and fruit weight and size were positively strongly related to each other in different growth stages (Table 4-6). It can be said that the different morphological attributes (length, breadth, weight and size) under this study were statistically significant at $p<0.01$ level and possesses differences (Table 7).

The systematic position of Nyctanthes under the family was controversial and showed affinity with Verbenaceae (26). The presence of tiny crystals (5-10 $\mu \mathrm{m}$ in length) is a distinguishing feature of the family Oleaceae $(27,28)$. The presence of prismatic crystals in epicarp cells of $N$. arbor-tristis is a good taxonomic tool to support the taxa as a member of the family Oleaceae. Not only crystals but the presence of anomocytic stomata also supports that the taxa is of Oleaceae.

The main function of the fruit is to store food materials, but green fruits can act as photosynthetic organ also and possesses stomata for gaseous 
exchange. The SF of fruit surface is 10-100 times lower than SF of the abaxial leaf surface of the same taxa indicating the functional differences (29-31). According to an earlier study (3), SF of $N$. arbor-tristis leaf varied from 211.11-488.88 per $\mathrm{mm}^{2}$ and present study shows that SF of the fruit ranges from 16.6783.33 per $\mathrm{mm}^{2}$, so, this data indicates the striking similarity of the previous works (29-31) and the difference also represents the functional dissimilarity of the two different organs of a same plant.

Surface sculpturing of plant cells may indicate its ecological habitat and it is seen that plants growing in dry conditions having more surface sculpturing with rough texture than those living in hydrophytic conditions (19). The wavy sculpturing, uneven cuticle deposition of epicarp cell and rough surface texture of this fruit study also supports its dry terrestrial habitat.

\section{Conclusion}

The duration of fruit maturity of Nyctanthes arbortristis L. takes about four months from blooming. In our study, we got optimum size matured green fruit in January-February and ripe fruit in late FebruaryMarch. The presence of anomocytic stomata, crystals, trichome, brachysclereids, narrow campanulate calyx, bilocular ovary also supports to its present position under Oleaceae rather than Verbenaceae. So, this unique structure and features of the fruit, seed and its phenological, morphological data will be helpful for taxonomists and further research works related to it. The presence of brachysclereid or stone cell in the seed coat also indicates its gritty texture at maturity. This work also indicates that the micromorphological data also supports the functional difference of two different organs of the same taxa. Further research on low seed yielding capacity of elliptical fruit is needed.

\section{Acknowledgements}

The first author is very much thankful to West Bengal state SVMCM Non-NET (Id. No.: WBP191577957462) authority for financial assistance. The authors are also grateful to NBU-USIC workers for their continuous support during SEM conductance.

\section{Authors' contributions}

KM carried out field visits, plant sample collection, identification, lab works, analysis, illustrations preparation and initial manuscript writing. MC identified the sample, supervised the whole work, and corrected the manuscript for submission.

\section{Conflict of interests}

Both authors declare that they have no conflict of interests.

\section{References}

1. Giuliani C, Tani C, Bini LM. Micromorphology and anatomy of fruits and seeds of bitter melon (Momordica charantia L.,
Cucurbitaceae). Acta Societatis Botanicorum Poloniae. 2016; 85(1):3490. https://doi.org/10.5586/asbp.3490

2. Sasmal D, Das S, Basu SP. Phytoconstituents and therapeutic potential of Nyctanthes arbor-tritis Linn. Pharmacognosy Reviews. 2007;1(2):344-49.

3. Biswas I. Studies on certain pharmacognostic aspects of Nyctanthes arbor-tristis L. Ph.D [dissertation]. Department of Botany, University of Burdwan; 2013. Available from: http://hdl.handle.net/10603/71441

4. Bhalakiya H, Modi NR. Traditional medicinal uses, phytochemical profile and pharmacological activities of Nyctanthes arbor-tristis. Research Journal of Life Sciences, Bioinformatics, Pharmaceutical and Chemical Sciences. 2019;5(2):1003-23. https://doi.org/10.26479/2019.0502.76

5. Tandon JS, Srivastava V, Guru PY. Iridoids: a new class of leishmanicidal agents from Nyctanthes arbor-tristis. Journal of Natural Products. 1991;54(4):1102-04. https://doi.org/10.1021/np50076a030

6. Jain R, Mittal M. A review on pharmacological and chemical documentation of Nyctanthes arbor-tristis Linn. (Harsingar). Asian Journal of Traditional Medicines. 2011;6(5):188-202.

7. Balasubramanian M. Study on phytochemical screening and anti-bacterial activity of Nyctanthes arbor-tristis. Journal of Chemical and Pharmaceutical Research. 2012;4(3):1686-95.

8. Prasad MP, Shekhar S. In-vitro phytochemical and antimicrobial activity of Nyctanthes arbor-tristis Linn. against human pathogens. International Journal of Pure Applied Bioscience. 2014;2(1):1-5.

9. Rani C, Chawla S, Mangal M, Mangal AK, Kajla S, Dhawan AK. Nyctanthes arbor-tristis Linn. (Night Jasmine): A sacred ornamental plant with immense medicinal potentials. Indian Journal of Traditional Knowledge. 2012;11(3):427-35. http://nopr.niscair.res.in/handle/123456789/14383

10. Rahman MM, Roy SK, Shahjahan M. Fatty acid composition of ripe seed oil of Nyctanthes arbor-tristis L. Journal of Bangladesh Academy of Sciences. 2011;35(1):121-24. https://doi.org/10.3329/jbas.v35i1.7977

11. Rahman MM, Shahjahan M. Analysis of fatty acid composition and physico-chemical characteristic of Nyctanthes arbor-tristis aged green seed and ripe seed by gas liquid chromatography. International Journal of Current Research and Review. 2012;4(23):9-15.

12. Globe. Soil pH protocol. Global learning and observations to benefit the environment. [Internet]. [cited 2020 Jan 21]. Available from: https://www.globe.gov/search-results

13. Prain D. Bengal Plants. Vol. 1. West, Newman \& Co. Printers and Publishers, Calcutta \& London; 1903. p. 656-60.

14. Ranjan V, Singh P, Lakshminarasimhan P, Dash SS, Chowdhery HJ. Flora of West Bengal. Vol. 3. Botanical Survey of India, Kolkata; 2015. p.358-69.

15. Jain SK, Rao RR. A Handbook of Field and Herbarium Methods. Today and Tomorrow's Printer and Publishers, New Delhi; 1977.

16. Spjut RW. A systematic Treatment of Fruit Types. New York Botanical Garden, U.S.A.; 1994. p. 1-182.

17. Nalawade AS, Gurav RV. Stomatal studies in the genus Chlorophytum (Asparagaceae). Bioscience Discovery. 2017;8(3):574-81.

18. Murley MR. Seeds of the Cruciferae of northeastern North America. American Midland Naturalist. 1951;46(1):1-81. https://doi.org/10.2307/2421948

19. Barthlott W. Epidermal and seed surface characters of plants: systematic applicability and some evolutionary aspects. Nordic Journal of Botany. 1981;1(3):345-55. https://doi.org/10.1111/j.1756-1051.1981.tb00704.x

20. Song JH, Hong SP. Fruit and seed micromorphology and its systematic significance in tribe Sorbarieae (Rosaceae). Plant Systematics and Evolution. 2020;306(6):1-14. https://doi.org/10.1007/s00606-020-01640-4

21. Paul P, Chowdhury M. Foliar micromorphology as a tool for identification of Indian taxa of Polygonaceae. Journal of Asia- 
Pacific Biodiversity.

https://doi.org/10.1016/j.japb.2021.05.008

22. Salisbury EJ. On the cause and ecological significance of stomatal frequency, with special reference to the woodland flora. Philosophical Transaction of the Royal Society B. 1927;216(431-439):1-65. https://doi.org/10.1098/rstb.1928.0001

23. Wallander E, Albert VA. Phylogeny and classification of Oleaceae based on rps16 and trnl-F sequence data. American Journal of Botany. 2000;87(12):1827-41. https://doi.org/10.2307/2656836

24. Kumari K, Yadav S. Linear regression analysis study. Journal of the Practice of Cardiovascular Sciences. 2018;4(1):33-36. https://doi.org/10.4103/jpcs.jpcs_8_18

25. Shinde PR, Sali VA, Patil PS, Bairagi VA. Assessment of pharmacognostic, phytochemical and antibacterial potential of fruit of Nyctanthes arbor-tristis Linn. Journal of Pharmacognosy and Phytochemistry. 2014;2(6):203-12.

26. Shaw HK. Notes on the taxonomic position of Nyctanthes and Dimetra. Kew Bulletin. 1952;271-72. https://doi.org/10.2307/4109278

27. Lersten NR, Horner HT. Crystal diversity and macro patterns in leaves of Oleaceae. Plant Systematics and Evolution. 2009;282(1):87-102. https://doi.org/10.1007/s00606-009-0209-1

28. Song JH, Hong SP. Comparative anatomy of petiole in Forsythieae, Fontanesieae and Myxopyrum (Oleaceae) and its systematic implication. Korean Journal of Plant Taxonomy. 2012;42(1):50-63. https://doi.org/10.11110/kjpt.2012.42.1.050
29. Blanke MM, Lenz F. Fruit photosynthesis - a review. Plant, Cell and Environment. 1989;12(1):31-46. https://doi.org/10.1111/j.1365-3040.1989.tb01914.x

30. Aschan H, Pfanz H. Non-foliar photosynthesis - a strategy of additional carbon acquisition. Flora. 2003;198:81-97. https://doi.org/10.1078/0367-2530-00080

31. Sánchez C, Fischer G, Sanjuanelo DW. Stomatal behavior in fruits and leaves of the purple passion fruit (Passiflora edulis Sims) and fruits and cladodes of the yellow pitaya [Hylocereus megalanthus (K. Schum. ex Vaupel) Ralf Bauer]. Agronomía Colombiana. 2013;31(1):38-47.

Additional information

Peer review information: Plant Science Today thanks Sectional Editor and the other anonymous reviewers for their contribution to the peer review of this work.

Reprints and permissions information is available at

https://horizonepublishing.com/journals/index.php/PST/open_access_policy

Publisher's Note: Horizon e-Publishing Group remains neutral with regard to jurisdictional claims in published maps and institutional affiliations.

To cite this article: Modak K, Chowdhury M. Morphological study of Nyctanthes arbor-tristis L. fruit and seed in different growth stages. Plant Science Today. 2021;8(4):778-785. https://doi.org/10.14719/pst.2021.8.4.1174

Plant Science Today, published by Horizon e-Publishing Group, is covered by Scopus, Web of Science, BIOSIS Previews, Clarivate Analytics, etc. See https://horizonepublishing.com/journals/index.php/PST/indexing_abstracting 